\title{
A revised ocean glider concept to realize Stommel's vision and supplement Argo floats
}

\author{
Erik M. Bruvik ${ }^{1}$, Ilker Fer ${ }^{1,2}$, Kjetil Våge ${ }^{1,2}$, and Peter M. Haugan ${ }^{1,3}$ \\ ${ }^{1}$ Geophysical Institute, University of Bergen, Bergen, Norway \\ ${ }^{2}$ Bjerknes Centre for Climate Research, University of Bergen, Bergen, Norway \\ ${ }^{3}$ Institute of Marine Research, Bergen, Norway
}

Correspondence: Ilker Fer (ilker.fer@uib.no)

Received: 11 April 2019 - Discussion started: 2 May 2019

Revised: 25 November 2019 - Accepted: 23 January 2020 - Published: 6 March 2020

\begin{abstract}
This paper revisits Stommel's vision for a global glider network and the Argo design specification. A concept of floats with wings, so-called slow underwater gliders, is explored. An analysis of the energy or power consumption shows that, by operating gliders with half the vehicle volume at half the speed compared to present gliders, the energy requirements for long-duration missions can be met with available battery capacities. Simulation experiments of slow gliders are conducted using the horizontal current fields from an eddy-permitting ocean reanalysis product. By employing a semi-Lagrangian, streamwise navigation whereby the glider steers at right angles to ocean currents, we show that the concept is feasible. The simulated glider tracks demonstrate the potential for efficient coverage of key oceanographic features and variability.
\end{abstract}

\section{Introduction}

In Stommel's (1989) vision for the year 2021, oceans would be monitored using instruments with wings. These robots would profile through the water column by changing their buoyancy in alternating vertical cycles of ascents and descents, with their wings providing the horizontal propulsion to "glide" through the oceans. It is now timely to look back and revisit this vision and assess its status.

Today, the oceans are indeed extensively monitored by buoyancy-driven robots - albeit without wings. These instruments are called floats, and approximately 4000 floats profile the oceans in the Argo programme (Roemmich et al., 2009). Their contribution to the knowledge of the oceans is substan- tial (Riser et al., 2016), yet juxtaposing the Argo programme and Stommel's vision invites a curious investigation as to why the floats lack wings. In that sense floats fall short of realizing his vision recognizing that wings would also allow for dynamic positioning. The original Argo design specification (Roemmich et al., 1999, p. 3) explicitly mentions the possibility of a winged gliding float:

a profiling float equipped with wings for dynamic positioning during ascent and descent, offers further potential. This 'gliding' float will provide a similar number of $T / S$ [temperature and salinity] profiles at a fixed location or along a programmed track.

The stated potential has not yet been realized and further motivates the inquiry presented here.

Floats, without wings, are now a robust and mature technology developed since the 1950s (Gould, 2005; Davis et al., 2001). Underwater gliders, floats with wings (hereafter referred to as gliders), are a newer, more complex development starting in the 1990s. The first successful glider designs materialized in the early 2000s (Davis et al., 2002; Jenkins et al., 2003) and have by now demonstrated their role as a reliable and useful tool for oceanographic exploration of phenomena, e.g. boundary currents where floats typically have short residence times (Rudnick, 2016; Lee and Rudnick, 2018). As the glider technology matured, the enthusiasm has gradually cooled (Rudnick, 2016). Gliders also fell short of realizing Stommel's vision. For instance, Stommel envisioned a global glider effort, compared to the current regional efforts; he envisioned endurance of years compared to months; and he foresaw 1000 gliders compared to a few 
tens in operation simultaneously. In one aspect current gliders do meet Stommel's expectation: their horizontal velocity is indeed approximately $25 \mathrm{~cm} \mathrm{~s}^{-1}$. We will, in the following, dispense with this latter requirement and argue that his vision may thereby be potentially realized.

Stommel never seriously assessed the power requirements, suggesting instead that gliders could harvest energy from the ocean thermocline. This has proved less than practical and is also not a solution for the global ocean.

Current glider designs (Sherman et al., 2001; Eriksen et al., 2001; and Webb et al., 2001) operate roughly according to the maxim " $1 / 2$ knot at $1 / 2 \mathrm{~W}$ "; i.e. they glide through the ocean at a horizontal velocity of roughly half a knot $\left(25 \mathrm{~cm} \mathrm{~s}^{-1}\right)$ consuming about half a Watt of power. We will in this paper rather pursue and propose an alternative operating point of " $1 / 4$ knot at $1 / 16 \mathrm{~W}$ ", which substantially increases the endurance of gliders. Provided that costs are comparable, if the endurance of gliders could match that of floats, then we would expect gliders to match floats in numbers and application.

\section{Fundamental considerations}

\subsection{Energy}

Consider first the profiling vehicle (float or glider) of volume $V_{0}$ at rest at a certain depth or pressure $p_{0}$. The ascent toward the ocean surface is initiated by increasing the volume by $\Delta V_{0}$, typically by pumping fluid from an internal to an external reservoir. This initial pumping supplies all the energy, $p_{0} \Delta V_{0}$, needed to propel the vehicle to the surface.

However, due to ocean stratification additional pumping is necessary as the vehicle rises to maintain the initial excess buoyancy $\Delta V_{0}$. Most of the in situ ocean stratification is due to the compressibility of seawater, but temperature and salinity changes also contribute. The total energy thus expended may be expressed as

$E=p_{0} \Delta V_{0}+\frac{1}{2} V_{0} p_{0}^{2}\left(\kappa_{\mathrm{w}}-\kappa_{\mathrm{h}}\right)+V_{0} \int_{0}^{p_{0}} p \frac{1}{\rho_{0}} \frac{\mathrm{d} \sigma_{t}}{\mathrm{~d} p} \mathrm{~d} p$,

where $\kappa_{\mathrm{w}}$ and $\kappa_{h}$ are the compressibility of seawater and vehicle hull respectively. The last term shows how ocean stratification from temperature and salinity, expressed by the density anomaly $\sigma_{t}$, costs additional energy. Note that this is also one of the main parameters we seek to measure during profiling.

Equation (1) ignores the effect of hull thermal expansion since it is small compared to seawater thermal expansion (but not negligible depending on the hull material). An exact equation must include the full equation of state (EOS) of both seawater and the vehicle hull (but then becomes intractable). Furthermore, all terms and integrands must be weighted with the efficiency of the buoyancy engine of a particular vehicle.

We have also only stated the energy usage for the ascent part of the dive-climb cycle, which is essentially the same for

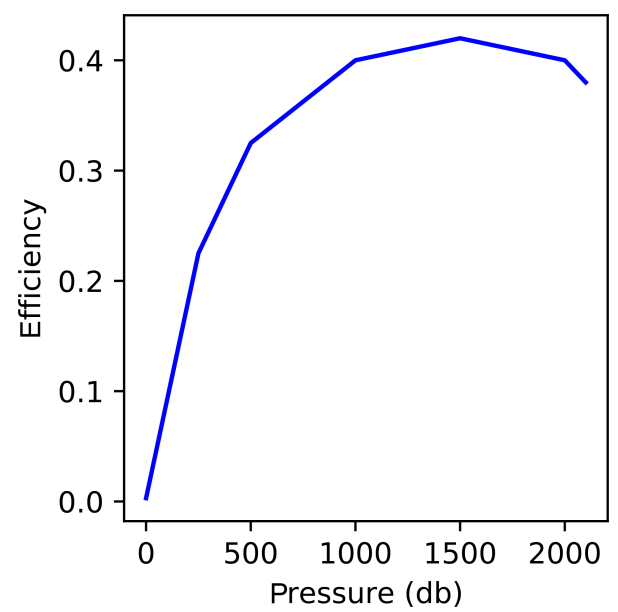

Figure 1. Typical buoyancy engine efficiency (electric to $p-V$ work) variation with profiling pressure.

both floats and gliders. Gliders generally operate in a symmetric mode in which the glider arrives at the target profile depth with a negative buoyancy equal to that used for the ascent $\left(\Delta V_{0}\right)$. Due to compressibility effects, descending floats typically settle more gradually at the target depth (Davis et al., 1992), possibly also with a pause or parking at an intermediate depth as is done with Argo floats (Argo, 2019a).

In the following we will assume a pump efficiency as indicated in Fig. 1. This is similar to pump efficiencies reported by Davis et al. (1992) and Kobayashi et al. (2010).

Further we will assume an aluminium hull with volumetric coefficient of thermal expansion of $7 \times 10^{-5}{ }^{\circ} \mathrm{C}^{-1}$ and a compressibility which is $90 \%$ of that of seawater $\left(4.42 \times 10^{-6} \mathrm{db}^{-1}\right)$. For the vehicle hull we may then use the following EOS:

$V(p, T)=V_{0}\left(1-\kappa_{\mathrm{h}}\left(p-p_{0}\right)+\alpha_{\mathrm{T}, \mathrm{h}}\left(T-T_{0}\right)\right)$,

where $\alpha_{\mathrm{T}, \mathrm{h}}$ is the volumetric thermal expansion coefficient of the hull and $p_{0}$ and $T_{0}$ are a reference pressure and temperature respectively. The EOS for seawater is given by TEOS-10 (IOC et al., 2010).

As an example, we calculate the energy consumed to ascend a tropical Atlantic profile from the World Ocean Atlas 2018 (Locarnini et al., 2018; Zweng et al., 2018) as shown in Fig. 2. Vehicle volume is set to $25 \mathrm{~L}$.

Equation (1) approximates the energy consumption well but slightly overestimated compared to the full EOS formulation. The difference (compare blue and red lines in Fig. 2d) is primarily due to Eq. (1) neglecting the thermal expansion of the hull (which will assist the vehicle in reaching the surface). 

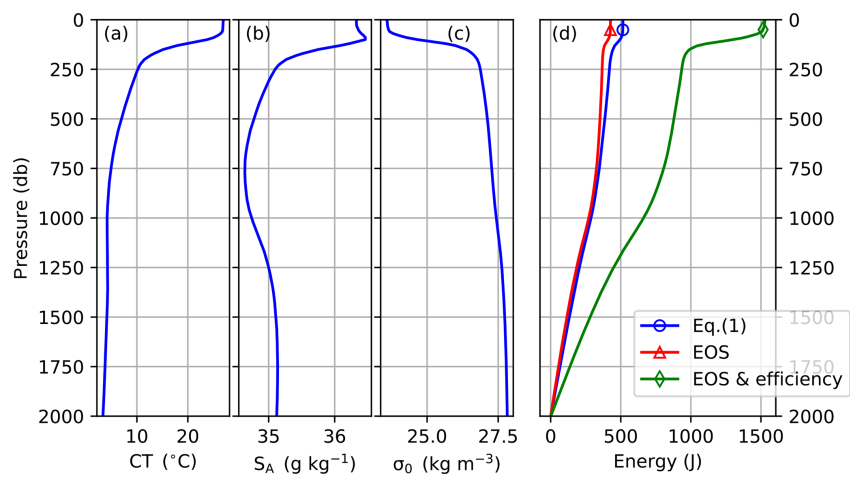

Figure 2. Profiles of (a) conservative temperature, (b) absolute salinity, (c) potential density anomaly and (d) energy consumed. The energy shown is that required to ascend from $2000 \mathrm{db}$ toward surface estimated by the two last terms of Eq. (1) (blue), calculated from the full EOS of both water and hull (red) and also accounting for the pump efficiency from Fig. 1 (green). The example profile is from the tropical Atlantic (WOA18; $5.5^{\circ} \mathrm{S}, 25.5^{\circ} \mathrm{W}$ ).

\subsection{Drag and power}

The drag force acting on the vehicle may be expressed as (Khoury and Gillett, 1999):

$\boldsymbol{F}_{D}=\frac{1}{2} \rho V_{0}^{2 / 3} C_{\mathrm{DV}}|\boldsymbol{v}| \boldsymbol{v}$,

where $\rho$ is the density and $C_{\mathrm{DV}}$ is the volume-based surface area referenced coefficient of drag and $v$ is the 3-D velocity vector of the vehicle. The area, $V_{0}^{2 / 3}$, can be replaced by any other reference area deemed suitable, such as the crosssection, length-squared or, as commonly done in aircraft design, the planform area of the wings (Hoerner, 1965). We choose the volume-based area since we expect drag to be dominated by skin friction, which would scale with the wetted surface area. It should be noted that different shapes will have different $C_{\mathrm{DV}} \mathrm{s}$, but for a given shape, Eq. (3) is also indicative of the scaling of drag with vehicle volume.

The power required, i.e. the product of force and velocity, is thus

$P=\frac{1}{2} \rho V_{0}^{2 / 3} C_{\mathrm{DV}}|\boldsymbol{v}|^{3}$,

which was advertised in the Introduction for the operation point $1 / 4 \mathrm{knot}$ at $1 / 16 \mathrm{~W}$. We will use $13 \mathrm{~cm} \mathrm{~s}^{-1}(1 / 4 \mathrm{knot})$ as a reference velocity for the rest of the paper (note that we refer to the horizontal velocity and not $|\boldsymbol{v}|)$.

\subsection{Lift}

For a winged vehicle, i.e. glider, lift is generated by the wings (Anderson, 2011; Thomas, 1999). It is known that wings are not efficient in flow with low speeds (low Reynolds numbers) (Schmitz, 1975; McMasters, 1974); however, Sunada et al. (2002) demonstrate that wings at low Reynolds numbers will perform adequately. At low speeds lift-to-drag ratios will be low (5-10) but sufficient for ocean profiling.

The generation of lift also causes so-called induced drag. In other words, the drag coefficient is also a function of the vehicle's angle relative to the direction of flow past the vehicle (the angle of attack). This effect is discussed in greater detail by Anderson (2011) and Thomas (1999) and is reasonably small here.

Categorized as flying vehicles, gliders (as discussed herein) operate in the regime of paper planes, small birds and large insects.

\subsection{Velocity and hydrodynamic model}

A hydrodynamic model is needed to calculate the vertical and horizontal components of the vehicle velocity arising from the action of the drag and lift forces. We define the hydrodynamic model in its abstract and implicit form:

Given expressions for vehicle drag and lift, and values for vehicle net buoyancy and orientation (pitch angle), apply Newton's first law to solve for the velocity and the angle of attack in conditions of steady planar flight.

The vehicle will then glide through the water at an angle which is the sum of pitch angle and angle of attack $(\alpha)$. As each glider can have different expressions for drag and lift, and we are here concerned with a hypothetical glider, we do not elaborate further on the hydrodynamic model and refer to Merckelbach et al. (2010, 2019), Graver (2005) (Sect. 5.1.3); Eriksen et al. (2001) and Sherman et al. (2001) for suitable expressions and parameterizations for lift and drag.

The angle of attack, however, deserves a comment in relation to lift and drag. Lift is proportional to angle of attack until the vehicle stalls and the production of lift reduces abruptly. In slow flight in particularly, caution must be exercised not to exceed the stall angle of attack. Drag resulting from the generation of lift, i.e. induced drag, is proportional to $\alpha^{2}$, hence small for small values of $\alpha$ (but not negligible).

In Fig. 3 we show the results from hydrodynamic models of two widely used gliders: the Seaglider (Eriksen et al., 2001; Frajka-Williams et al., 2011) and the Slocum glider (Webb et al., 2001; Merckelbach et al., 2010, 2019). The Seaglider has a relatively larger surface area and hence more drag. At higher velocities and buoyancies, however, the laminar flow profile of the Seaglider improves the performance relative to the Slocum glider. We also show the performance, in terms of velocity, of a hypothetical Slocum glider with half the volume and $20 \%$ reduced drag. The reduction in volume is discussed in the next section. The $20 \%$ lower drag is justified since Eq. (3) indicates a drag reduction of $37 \%$ for a vehicle with half the volume. We deem $20 \%$ drag reduction to be a conservative estimate and will account for induced drag and parasitic drag from appendages not represented in Eq. (3). The lift and size of the wings of this hypothetical 


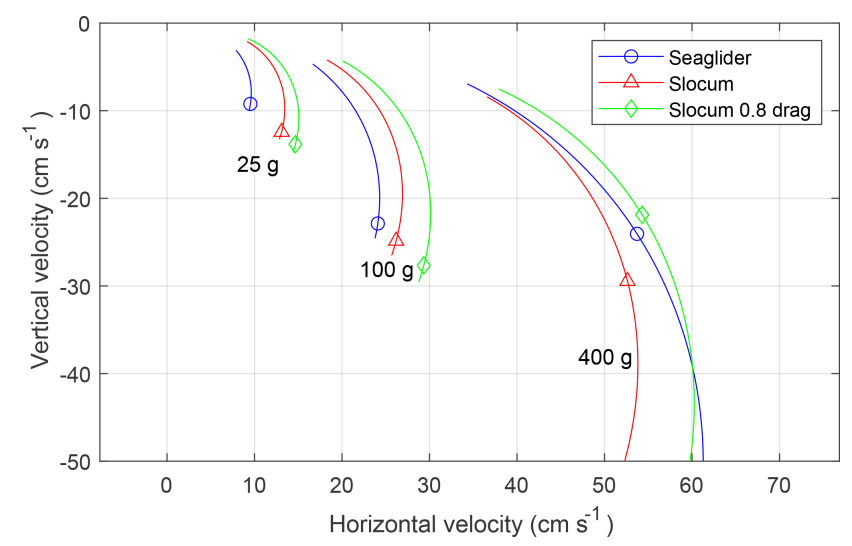

Figure 3. Performance as reflected in velocity (speed polars) of the Seaglider and the Slocum glider for three different net buoyancies of 25, 100 and $400 \mathrm{~g}$. Also shown: a hypothetical Slocum glider with half volume and $20 \%$ reduced drag. At low vertical speeds, the polars are cut off at an angle of attack of $5^{\circ}$. The angle of attack decreases with increasing vertical velocity.

glider are left unchanged, but it might be necessary to increase the size of the wings slightly, to compensate for the reduction in lift from a smaller hull (Merckelbach et al., 2010).

Our discussion about the performance of a glider with smaller volume is preliminary. A careful glider design should include simulations (Lidtke et al., 2018), tank tests (Sherman et al., 2001), tank tests in combination with simulations (Jagadeesh et al., 2009) and field tests where velocities are measured (Eriksen et al., 2001; Merckelbach et al., 2019). We find the extrapolation for the hypothetical glider toward a slower velocity and lower buoyancy to be safe and expect no significant Reynolds number effects, neither on lift nor drag. For speeds of $O\left(10 \mathrm{~cm} \mathrm{~s}^{-1}\right)$, glider Reynolds numbers are of the order of $10^{4}$ and $10^{5}$ for wing chords $(\sim 10 \mathrm{~cm})$ and vehicle lengths $(\sim 100 \mathrm{~cm})$ respectively.

We see in Fig. 3 that the modified Slocum glider with $80 \%$ drag can achieve the desired horizontal velocity of $13 \mathrm{~cm} \mathrm{~s}^{-1}$ for a vertical velocity of $5 \mathrm{~cm} \mathrm{~s}^{-1}$ at a net buoyancy force of $25 \mathrm{~g}(0.245 \mathrm{~N})$ and at an acceptable angle of attack $(\alpha<5)$. This translates to a horizontal displacement through water of $2.6 \mathrm{~m} \mathrm{I} \mathrm{m}^{-1}$ of profile depth and a cycle period of almost day for a $2000 \mathrm{~m}(2031 \mathrm{db})$ deep profile. The profile depth is chosen primarily to be compatible with Argo float sampling and to escape surface currents which tend to be larger than currents at depth.

The low excess buoyancy of $25 \mathrm{~cm}^{3}$ will be challenging to maintain over the dive in the face of ocean in situ stratification. We have expressed the energy required to maintain this excess buoyancy as a continuous function in Eq. (1). The result of the calculation is depicted in Fig. 2d as a continuous curve. A real vertical velocity or buoyancy controller will discretize this curve as needed based on the observed depth rate which might have to be monitored frequently.

\subsection{Preliminary discussion}

All propulsive energy, pressure-volume work $p_{0} \Delta V_{0}$, initially supplied will eventually be used to overcome drag. We need not consider residual kinetic energy when the vehicle reaches the surface since it is of the order of $1 \mathrm{~J}$ at the low speeds involved here, and the terms of Eq. (1) are typically $O(1 \mathrm{~kJ})$.

Based on the definition of work we restate Eq. (1) with the drag expression, Eq. (3), inserted and integrated over a linear path $s$ (distance) to the surface:

$$
\begin{aligned}
E & =\frac{1}{2} \rho V_{0}^{2 / 3} C_{\mathrm{DV}}|\boldsymbol{v}|^{2} s+\frac{1}{2} V_{0} p_{0}^{2}\left(\kappa_{\mathrm{W}}-\kappa_{\mathrm{h}}\right) \\
& +V_{0} \int_{0}^{p_{0}} p \frac{1}{\rho_{0}} \frac{\mathrm{d} \sigma_{t}}{\mathrm{~d} p} \mathrm{~d} p .
\end{aligned}
$$

The following considerations follow from this equation. The speed and vehicle volume should be as small as possible. The factor $V_{0}^{2 / 3}$ in the first term might indicate that larger vehicles are better (Jenkins et al., 2003). This effect, however, is reduced by the other terms, which are proportional to vehicle volume, especially for a profiling vehicle which must traverse the pycnocline (third term). Hull compressibility should match that of seawater, and this effect becomes increasingly important as profiling depth or pressure is increased.

The distance $s$ to the surface is simply the depth for a vertically profiling float. Gliders, with displacement in the horizontal direction, have a longer path depending on the glide angle. Thus, gliding inherently is a costlier endeavour than profiling vertically. Also, the equation indicates that the drag of the floats should be reduced for further energy savings. A stability disc was introduced to Argo primarily to ensure better stability and communication at the surface (Davis et al., 1992); however, it turns the float into a hydrodynamically blunt object. The stability disc is not needed on floats with faster telemetry and can be removed to lower the drag and energy consumed. Glider wings suppress heaving motions at the surface, offering relatively stable communication conditions.

Equation (5) in itself indicates no optimum, and instead a viable low energy consumption must be sought. Considerations including so-called hotelling loads arising from the energy consumed by sensors may introduce optima (Graver, 2005, Sect. 7.2.1; Jenkins et al., 2003) but fall outside of the scope of this paper. For the vision presented here, powerhungry sensors must be avoided. It is doubtful whether a pumped conductivity and temperature system could be employed on a slow glider. Unpumped conductivity cells have been successfully used in gliders, and after appropriate corrections (Lueck and Picklo, 1990; Garau et al., 2011) they supply data of adequate quality. Such corrections will be challenging for a relatively slow flow past the sensor in a slow glider, but technically possible, provided an adequate 
sampling rate and flushing of the conductivity cell (Kim Martini, personal communication, 2019). Further calibrations and bias removal will also be possible against Argo floats and ship-based measurements. The user must carefully assess the accuracy needed for salinity against a trade-off from endurance.

A net buoyancy change of $50 \mathrm{~cm}^{3}$ at the transition from descent to ascent at $2000 \mathrm{db}$ will consume $2.5 \mathrm{~kJ}$, assuming a pump efficiency of $40 \%$ (Davis et al., 1992). Assuming that the dive-climb and turning behaviour of a $1000 \mathrm{~m}$ rated Seaglider is representative of a slow glider, based on data from our glider missions operated from Bergen (next section), we estimate that heading control will consume approximately $1 \mathrm{~kJ}$ per dive for the compass electronics and the roll or yaw mechanics. Since $1 / 16 \mathrm{~W}$ corresponds to $5.4 \mathrm{~kJ} \mathrm{~d}^{-1}$, there will be $1.9 \mathrm{~kJ}$ remaining to expend on vehicle compressibility and ocean stratification (in a dive-climb cycle period of $1 \mathrm{~d}$ ). The power rating of $1 / 16 \mathrm{~W}$ is equivalent to $1.6 \mathrm{~kg} \mathrm{yr}^{-1}$ of lithium primary batteries ${ }^{1}$. These numbers are for vehicle propulsion and heading control only, and an operational glider should allow for an additional $1 / 16 \mathrm{~W}$ for sensors and communications.

Present gliders indeed look compact and crammed on the inside. Yet Eq. (5) clearly shows that volume drives energy consumption. As energy considerations are of prime importance, vehicle volume must come down. This would be achievable if the glider was designed with this consideration in mind from the start. This direction of development is necessary on the grounds of basic energy considerations. An example of a low-volume vehicle is the SOLO-II float, which has a volume of approximately $18 \mathrm{~L}-$ in its previous technological iteration, the SOLO-I float, it had a volume of $30 \mathrm{~L}$ (Owens et al., 2012). Reduction in volume seems possible. If glider volume could only be reduced to $30 \mathrm{~L}$ rather than $25 \mathrm{~L}$, Eq. (5), being almost linear in volume, shows that volume and energy consumption would both increase by roughly $20 \%$.

The $2000 \mathrm{~m}$ hull of the vehicle must satisfy three requirements. It must be strong enough to withstand pressure, yet the compressibility should match that of seawater, and finally, it should offer the necessary payload volume for batteries, electronics and the buoyancy engine. This poses a real engineering challenge. Jenkins et al. (2003, Sect. 6.3) contains detailed considerations for an aluminium hull. However, it is likely that alternative composite materials must be considered for the hull (Osse and Eriksen, 2007; Webb, 2006).

\footnotetext{
${ }^{1}$ Based on the current specification of the Electrochem 3B0036 DD lithium primary cell: https://s24.q4cdn.com/142631039/files/ pdf/3B0036-datasheet.pdf (last access: 26 February 2020). This is rated at $26 \mathrm{Ah}, 3.2 \mathrm{~V}$ at $1 \mathrm{~A}$ discharge; derated $10 \%$ for operation at $0{ }^{\circ} \mathrm{C}$, cell mass of $213 \mathrm{~g}$. This gives a specific energy content of $1.27 \mathrm{MJ} \mathrm{kg}^{-1}$.
}

In summary, we suggest that a slow glider (or float with wings) is feasible if the volume and speed are halved relative to present gliders.

\subsection{Overall power budget}

As an example of a complete power budget we use a lowpower and slow Seaglider dive. The dive was conducted in the Iceland Sea by Seaglider sg564 on 5 November 2015 (dive number 227). The vehicle was diving with a buoyancy of $\pm 21 \mathrm{~cm}^{3}$ only, and the average vertical velocity was $5 \mathrm{~cm} \mathrm{~s}^{-1}$. The horizontal velocity was only approximately $8.5 \mathrm{~cm} \mathrm{~s}^{-1}$, which is $35 \%$ slower than the velocity $\left(13 \mathrm{~cm} \mathrm{~s}^{-1}\right.$ ) advocated by us (Fig. 3 ).

The controller (processor) is the most power-hungry main component, with $37 \%$ of the total energy expenditure (Table 1). This, however, is not because of complex control but rather due to the fact that the processor of the glider is severely outdated. The controller of both Seagliders and Slocums is based on a processor design from the 1980s (the Motorola 68000-series) in a 1990s package (the Persistor). Based on a conservative application of Moore's law, we estimate that the power consumption could be reduced by a factor of 4 for a modern processor.

Only $6 \%$ of the total energy was expended on the conductivity, temperature and depth (CTD) sensor - a figure that should arguably be increased in order to apply appropriate corrections for free-flush conductivity cells. We would like to allocate savings from a new controller to increasing the number of CTD samples possibly including an $\mathrm{O}_{2}$ optode (0.7 J sample $\left.{ }^{-1}\right)$.

In this paper, we are mainly concerned with the energy expended by the buoyancy engine (Eqs. 1 and 5). Nevertheless, we allow for an additional $1 \mathrm{~kJ} 2000 \mathrm{~m}^{-1}$ dive to be allotted to vehicle heading and attitude control. This is justified by the fact that only $414 \mathrm{~J}$ were expended on this during the example $1000 \mathrm{~m}$ dive.

Power budgets will be related to the vehicle volume as the displacement must make up for the weight of batteries. If we allocate $1 / 16$ th of a Watt $(63 \mathrm{~mW})$ to vehicle propulsion and heading control and another $1 / 16$ th of a Watt to the controller, sensors and telemetry, that would correspond to a $6.2 \mathrm{~kg}$ lithium battery pack for a 2 -year mission. Although challenging, it is possible to fit this battery into a vehicle with a displacement of $25 \mathrm{~L}$. Please note how the example dive just falls slightly short of achieving the goal of 2/16th of a Watt (125 mW).

\subsection{Mission cost}

As a basis for estimating the mission cost we use the current costs for a core Argo float mission. The cost for the float itself is about USD 20000 which approximately doubles when programme management costs are included (Argo, 2019b). Basing the cost estimate on Argo float costs can be 
Table 1. Energy or power breakdown for low-power Seaglider dive to $1000 \mathrm{~m}$. Dive buoyancy was only $\pm 21 \mathrm{~cm}^{3}$, and dive duration was $11 \mathrm{~h}$. In total 860 CTD samples were collected (non-uniform vertical sampling with $20 \mathrm{~s}$ sampling rate in the upper $150 \mathrm{~m}$ ).

\begin{tabular}{|c|c|c|c|c|}
\hline Main component & Parts (subcomponent) & $\begin{array}{r}\text { Energy } \\
(\mathrm{J})\end{array}$ & $\begin{array}{l}\text { Power } \\
(\mathrm{mW})\end{array}$ & $\begin{array}{r}\text { Fraction } \\
(\%)\end{array}$ \\
\hline \multirow[t]{4}{*}{ Buoyancy engine } & At inflection/apogee & 1172 & 30 & 22 \\
\hline & Stratification & 282 & 7 & 5 \\
\hline & At surface & 179 & 5 & 3 \\
\hline & Sum & 1633 & 41 & 30 \\
\hline \multirow[t]{4}{*}{ Attitude mechanics and sensor } & Roll motor & 122 & 3 & 2 \\
\hline & Pitch motor & 82 & 2 & 2 \\
\hline & Attitude sensor & 210 & 5 & 4 \\
\hline & Sum & 414 & 10 & 8 \\
\hline \multirow[t]{3}{*}{ Controller } & Active (sampling, vehicle ctrl., etc.) & 1246 & 31 & 23 \\
\hline & Sleeping & 782 & 20 & 14 \\
\hline & Sum & 2028 & 51 & 37 \\
\hline \multirow[t]{3}{*}{ Sensors } & Temperature and conductivity & 149 & 4 & 3 \\
\hline & Depth (+ analog circuits) & 172 & 4 & 3 \\
\hline & Sum & 321 & 8 & 6 \\
\hline Telemetry & GPS and iridium & 1014 & 26 & 19 \\
\hline Total & & 5410 & 136 & 100 \\
\hline
\end{tabular}

justified for two reasons. The economy of scale for $O(1000)$ slow gliders would approach that of floats rather than present gliders, and a winged float has many parts in common with regular floats; the hull, the buoyancy engine, GPS, Iridium, CTD, etc.

In Table 2 we include the additional costs for various glider-specific items. A glider is inherently a more complex instrument than just a float with wings plus other components, and we also allow for costs associated with the increase in complexity of integrating the additional parts. Furthermore, we include a healthy profit of $50 \%$ and development costs. While the relative distribution of profit, component costs and operation costs can be different, the overall cost estimate is deemed representative.

The simple budget in Table 2 indicates that a slow glider (winged float) mission would cost about 3 times as much as an Argo float mission (USD 40000 ). This may or may not be deemed prohibitive depending on scientific potential and value of such an endeavour.

\section{Experimental glider trajectory simulation}

What missions would be possible with a glider travelling at only $13 \mathrm{~cm} \mathrm{~s}^{-1}$ ? In order to explore this question, we set up a simulation experiment using slow gliders. The gliders profile to $2000 \mathrm{~m}$ at a vertical velocity of $5 \mathrm{~cm} \mathrm{~s}^{-1}$ giving a cycle time of approximately $1 \mathrm{~d}(0.93 \mathrm{~d}$ to be precise $)$.
Table 2. Cost estimate for a slow glider mission based on Argo float costs and Argo programme costs.

\begin{tabular}{lr}
\hline Item & $\begin{array}{r}\text { cost } \\
\text { (thousands of USD) }\end{array}$ \\
\hline Core Argo float & 20 \\
Wings and fins & 1 \\
Roll and pitch assay & 5 \\
Attitude sensor and altimeter & 3 \\
Larger batteries & 3 \\
Complexity of integration & 10 \\
Profit of 50\% on above & 21 \\
Amortization of dev. costs & 10 \\
\hline Vehicle price & 73 \\
\hline Argo programme and data mgmt. & 20 \\
Mgmt. of complex programme and data & 10 \\
Piloting (semi-automatic) & 10 \\
Launch & 5 \\
Recovery & 10 \\
Value of recovered vehicle & 10 \\
\hline Program cost & 45 \\
\hline Mission cost & 118 \\
\hline
\end{tabular}




\subsection{Navigation}

In an environment where ocean current velocities typically exceed vehicle velocity, the navigation strategy must be adjusted, or else the vehicle is simply too slow for the normal navigational notions to be feasible. Specifically, navigation with traditional latitude and longitude waypoints along straight lines must be given up. Instead, we propose to navigate in Lagrangian streamwise coordinates.

The Lagrangian streamwise navigation is achieved when the glider steers at right angles to ocean currents and never attempts to compensate for these currents. Thus, it will be able to step into or out of any coherent current structure be it an eddy, a front or a boundary current. Trajectories will be spirals and oblique winding lines and not linear transects along bathymetric gradients. The glider will operate in a semi-Lagrangian and semi-Eulerian mode. This, however, represents a significant upgrade to Lagrangian only floats.

We call the proposed method of navigation "Eulerian roaming", where Eulerian refers to the streamline traversing capability and roaming to the Lagrangian drift. Colloquially one might be tempted to summarize the Eulerian roaming with two common sayings or proverbs: "only dead fish follow the flow" and "never oppose a stronger force - outmanoeuvre". Davis et al. (2009) summarize it as follows:

in a strong adverse current, steer rapidly across the current while making up ground where the currents are weak or favorable.

To the extent possible, in weak or favourable currents, one might still apply regular navigation. Lekien et al. (2008) address this problem.

Stommel (1989) notes the following: "Having to decide what heading to choose stimulated modellers and descriptive oceanographers to exercise their minds and their computers." We will attempt to do so in the following.

\subsection{Glider simulation in a reanalysed ocean}

In the simulation the gliders will attempt to navigate the reanalysed ocean of Mercator GLORYS12 provided by the Copernicus Marine Environment Monitoring Service (CMEMS). This reanalysis is based on the real-time global ocean forecasting of CMEMS which is detailed by Lellouche et al. (2018). The reanalysis is eddy permitting with a horizontal resolution of $1 / 12^{\circ}$ (approximately $8 \mathrm{~km}$ ) and 50 vertical levels. Temporally the output is given as daily means. For further details about the product we refer to the product user manual (CMEMS, 2018). For the purposes of the present simulation, the reanalysis need not be accurate but should be qualitatively realistic in order to mimic the real ocean to obtain representative simulated trajectories.

A fourth-order Runge-Kutta method with adaptive time steps (RK45) is used to integrate glider and ocean velocities to estimate the glider's position. The maximum time step is
$600 \mathrm{~s}$, but this is reduced to $60 \mathrm{~s}$ at the surface or near the bottom and otherwise adjusted automatically. The glider's horizontal velocity is fixed at $13 \mathrm{~cm} \mathrm{~s}^{-1}$ and the vertical velocity at $5 \mathrm{~cm} \mathrm{~s}^{-1}$. The horizontal speed of $13 \mathrm{~cm} \mathrm{~s}^{-1}$ was established in Sect. 2.4 (Fig. 3) for the operating point of $25 \mathrm{~cm}^{3}$ in excess buoyancy.

The velocity fields from the reanalysis product are linearly interpolated in space and time. The glider is advected in a Euclidian flat-earth coordinate system but re-projected per dive or if glider displacement exceeds $25 \mathrm{~km}$. We observe no artefacts arising from the numerical scheme, linear interpolation or spatial reference. The coarse bathymetry of the model with only 50 levels (steps increasing with depth) aggravates plunges steeper than the glider trajectory. When climbing bathymetry, the glider would occasionally fly into these plunges and get stuck, and in such cases the glider was jerked up $5 \mathrm{~m}$ at a time until the glider was clear of the bathymetry. This is not an issue for real gliders equipped with altimeters.

The drift at the surface, for about 5 to 10 min while communicating in between dives, is ignored. The results, however, are not sensitive to this.

\subsection{Navigational recipe}

The glider is steered according to the principles set out in Sect. 3.1. To express a recipe for the Eulerian roaming navigation we formulate the following pseudo-code or set of rules:

A. Traverse the ocean at $\pm 90^{\circ}$ relative to the measured average current over the previous dive (i.e. step into or out of a certain current feature).

B. If depth-average current is not available, steer along or opposite to the gradient of the local bathymetry.

C. If neither (A) nor (B), steer to the nearest current feature as indicated by satellite altimetry (or in future, as appearing in operational ocean nowcasts and forecasts).

D. If none of the above provide an informed heading, use an opportunistic heading deemed suitable for the mission in general.

The ordering of rules is not coincidental. They provide a hierarchy from the simplest autonomous modes $\left(\mathrm{A}\right.$ and $\left.\mathrm{B}^{2}\right)$ to complex autonomous modes only achievable by reliance on external sensors (altimetry and models) and human or artificial intelligence (rule $\mathrm{C}$ and $\mathrm{D}$ respectively). In the experiments presented here, we do not attempt to automate the selection of active rule, but future work must do this. For now, we rely on a skilled human pilot (a.k.a. artificial artificial intelligence).

\footnotetext{
${ }^{2}$ The glider could have a bathymetric map installed to autonomously calculate the topographic gradient.
} 
We suppose that an up-to-date and accurate map of sea surface heights ( $\mathrm{SSHs}$ ) is available, and to mimic this we use the SSH of the reanalysis as an input for the mode (C) above. As will be discussed in Sect. 4.5, we find this a reasonable assumption for the near future.

Occasionally the simulated glider visited ice-covered waters (eastern coast of Greenland), and we will here assume that the following under-ice navigation can be executed: head west under ice until the $500 \mathrm{~m}$ isobath, then turn back (without surfacing). This can be interpreted as an under-ice version of rule (B) above. Gliders today are equipped with iceavoidance algorithms (Renfrew et al., 2019), which make similar scenarios applicable.

\section{Results and discussion}

\subsection{The Nordic Seas}

To test the slow glider, we first simulate a mission in the Nordic Seas where we attempt to visit known features and currents. The Nordic Seas are bounded by Norway, Greenland, the Greenland-Scotland Ridge in the south, and Fram Strait in the north.

The mission, Fig. 4, starts off the west cape of Norway in the south at the $500 \mathrm{~m}$ isobath $\left(62.8^{\circ} \mathrm{N}, 4.25^{\circ} \mathrm{E}\right.$; 24 June 2015 at noon UTC). The glider first heads NW off the shelf slope. In the middle of the Norwegian Sea the glider heads NE into the Lofoten Basin, where it visits the semi-permanent anticyclone, the Lofoten Basin Eddy (Yu et al., 2017). It then crosses the Mohn Ridge into the Greenland Sea and proceeds NE to Spitsbergen, where it turns westward at the $500 \mathrm{~m}$ isobath. Unless otherwise noted, we always turn the glider near the continental shelf break, at the $500 \mathrm{~m}$ isobath. The glider then crosses Fram Strait westward to Greenland and then proceeds south to the Greenland Sea. After visiting the east Greenland shelf again, the glider heads for the Iceland Sea, works another section toward the Greenland shelf, and heads SE to cross the Iceland and Norwegian seas, reaching the recovery point where it was launched after 1.5 years at sea.

The mission executed can be summarized as follows: visit the main features of the Nordic Seas (excluding the shallow Barents Sea). Due to the relatively modest currents encountered we find that we may "ferry" the glider around according to rule (D) (Sect. 3.3) in the central parts of the basins. Near boundaries we used rules (A) and (B), which often resulted in the same heading.

The glider performs 691 cycles. The energy consumption, using the technique and values described in Sect. 2, is $2.9 \mathrm{MJ}$ (or $2.3 \mathrm{~kg}$ of lithium primary batteries). This is calculated by evaluating Eq. (1) using the established operating point with an excess buoyancy of $25 \mathrm{~cm}^{3}$ and using the salinity and temperature fields of the reanalysis product. Then $1 \mathrm{~kJ}$ is added per dive for heading or attitude control, and finally $0.5 \mathrm{~kJ}$ is

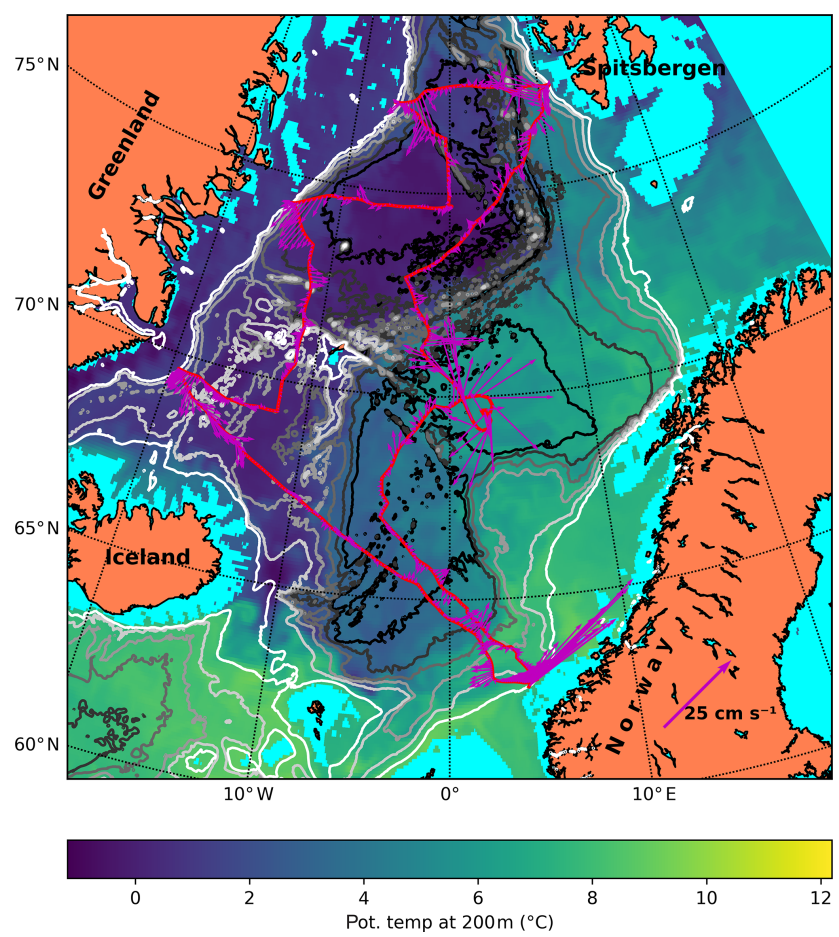

Figure 4. Slow glider mission in the Nordic Seas. The glider mission starts at the south-eastern corner, off Norway at $62.8^{\circ} \mathrm{N}$ $4.25^{\circ} \mathrm{E}$ at the $500 \mathrm{~m}$ isobath, and returns 1.5 years later. The glider track proceeds anticlockwise. Bathymetric contours are drawn at $500 \mathrm{~m}$ intervals. Arrows indicate depth-averaged currents measured or experienced by the glider (e.g. Rudnick et al., 2018). The temperature at $200 \mathrm{~m}$ is also shown to indicate water mass distribution: $T>4{ }^{\circ} \mathrm{C}$ is typically Atlantic water with $S>35$. Note that the temperature at $200 \mathrm{~m}$ introduces an implicit isobath at $200 \mathrm{~m}$, leaving shelves in a light blue colour.

added for surface pumping to raise the antenna out of the water. The full EOS of water and hull (Eq. 2) is taken into consideration. Values for compressibility and thermal expansion are as given in Sect. 2.1 and the result of the calculation is depicted in Fig. 2 d.

\subsection{Gulf Stream}

In order to test the slow glider in a more challenging, energetic environment, we visit the Gulf Stream.

This mission, Fig. 5, starts at the coast of Florida and Georgia (again at the $500 \mathrm{~m}$ isobath; $30^{\circ} \mathrm{N}, 80^{\circ} \mathrm{W} ; 27$ September 2015 , noon UTC). The glider is rapidly advected NE by the strong currents but is able to probe the Gulf Stream twice before it, together with the Gulf Stream, leaves the shelf break $\left(35^{\circ} \mathrm{N}\right)$. The rapid advection with the stream continues, but not uncontrollably: at $66^{\circ} \mathrm{W}$ the glider intentionally visits a cold-core ring. Around $56^{\circ} \mathrm{W}$ the glider is caught up in an energetic meander of the Gulf Stream. The time and location of where the glider was ejected out of this meander were somewhat coincidental. 


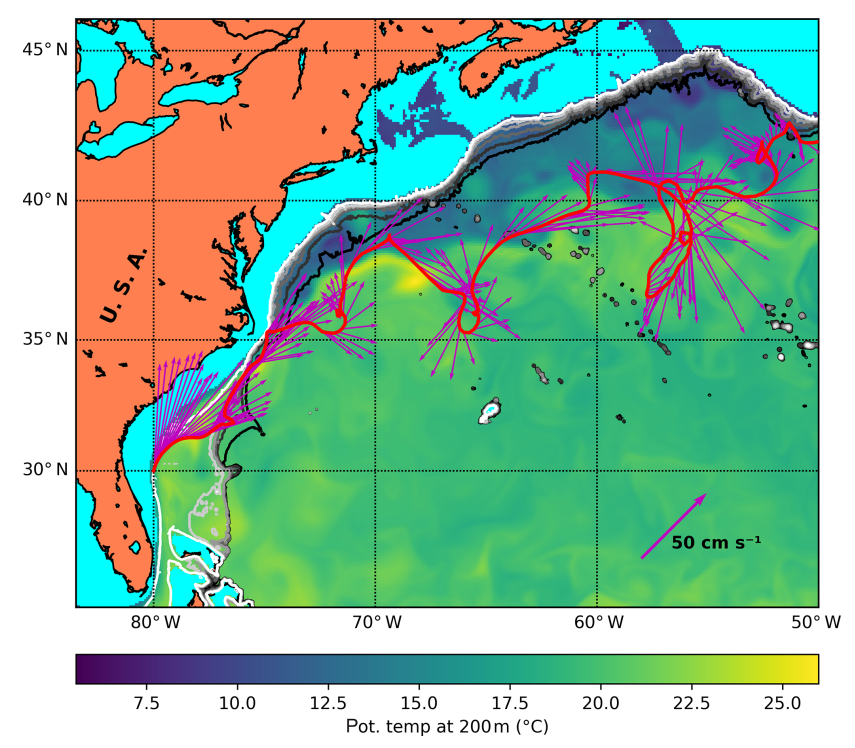

Figure 5. Slow glider in the Gulf Stream off the east coast of the USA. The glider starts at the coast of Florida at the $500 \mathrm{~m}$ isobath. Bathymetric contours drawn at $500 \mathrm{~m}$ intervals to $3000 \mathrm{~m}$. The temperature at $200 \mathrm{~m}$ is also shown to represent the water mass distribution.

The Eulerian roaming through this energetic environment is realistic and has been successfully performed previously. Using Spray gliders, Todd et al. (2016) collected transects across the Loop Current in the Gulf of Mexico and across the Gulf Stream between 35 and $41^{\circ} \mathrm{N}$, downstream of Cape Hatteras. To collect these sections, the gliders were instructed to attempt to fly at right angles to the measured flow (horizontal speed of the Spray glider through the water was approximately $25 \mathrm{~cm} \mathrm{~s}^{-1}$; the vertically averaged speed of the western boundary current regularly exceeded $1 \mathrm{~m} \mathrm{~s}^{-1}$ ). The Spray gliders were operated to a maximum of $1000 \mathrm{~m}$ depth, using the so-called "current-crossing navigation mode", in which the glider adjusts its heading after each dive to steer a fixed direction relative to measured depth-averaged currents (Todd et al., 2016). This navigation mode is similar to our rule (A). It is thus demonstrated that a glider can persistently progress across a strong and variable current without continuous intervention of a pilot.

Since our hypothetical glider ended up off Newfoundland, it was natural to continue the mission into the northern branch of the North Atlantic Current (NAC), and the continuation of the mission is shown in Fig. 6.

At $55^{\circ} \mathrm{N}$ the decision is made to visit the southern tip of Greenland rather than continuing up along the Reykjanes Ridge to Iceland. From the southern tip of Greenland, it would be possible to work the Subpolar Gyre, but we opted to head for recovery at Iceland where the glider arrives after 721 cycles, after 1.8 years. Energy consumption is estimated at $3.4 \mathrm{MJ}$, equivalent to approximately $2.7 \mathrm{~kg}$ of lithium primary batteries.

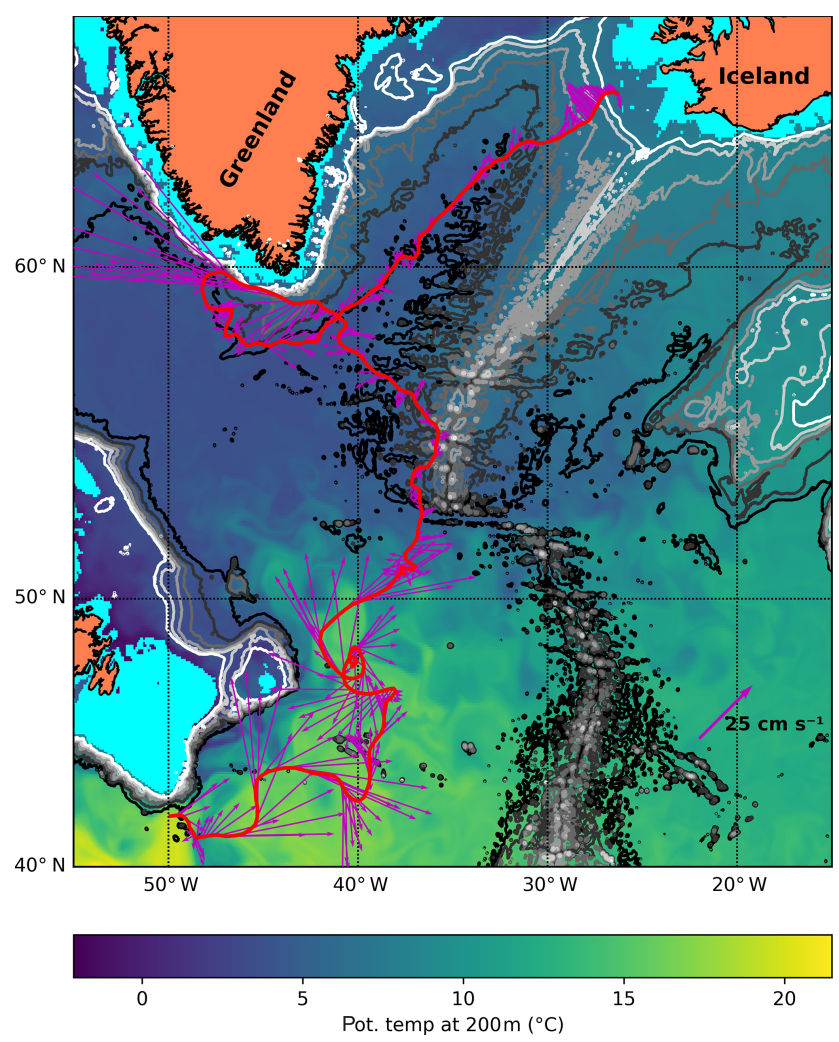

Figure 6. Slow glider mission continued into the North Atlantic Current. The glider ends at Iceland in the north-eastern corner of the map. Bathymetric contours are at $500 \mathrm{~m}$ intervals. The temperature at $200 \mathrm{~m}$ is also shown.

\subsection{Drake Passage}

The Drake Passage between the South American and the Antarctic continents probably represents the world's most interesting choke point (or area) as the Antarctic Circumpolar Current (ACC) must pass through it, and we simulate a mission here as well.

The glider is launched off the tip of South America $\left(67.8^{\circ} \mathrm{W}, 56.97^{\circ} \mathrm{S}\right.$; 26 May 2015) and attempts a transect southward across the Drake Passage. For the Drake Passage part of this mission, we attempt to do linear transects with a direct crossing of the passage. However, the slow glider is advected out of the passage in two transects (Fig. 7). This is due to the general flow of the ACC in the passage - it is simply not possible to perform a transect without drift-off here with a slow glider.

After being advected out of the Drake Passage, the glider is capable of staying in the Scotia Sea to the east, where it executes a distorted butterfly before recovery at South Georgia Island after 638 cycles. Energy consumption is estimated at $3.1 \mathrm{MJ}(2.5 \mathrm{~kg}$ of lithium primary batteries). 


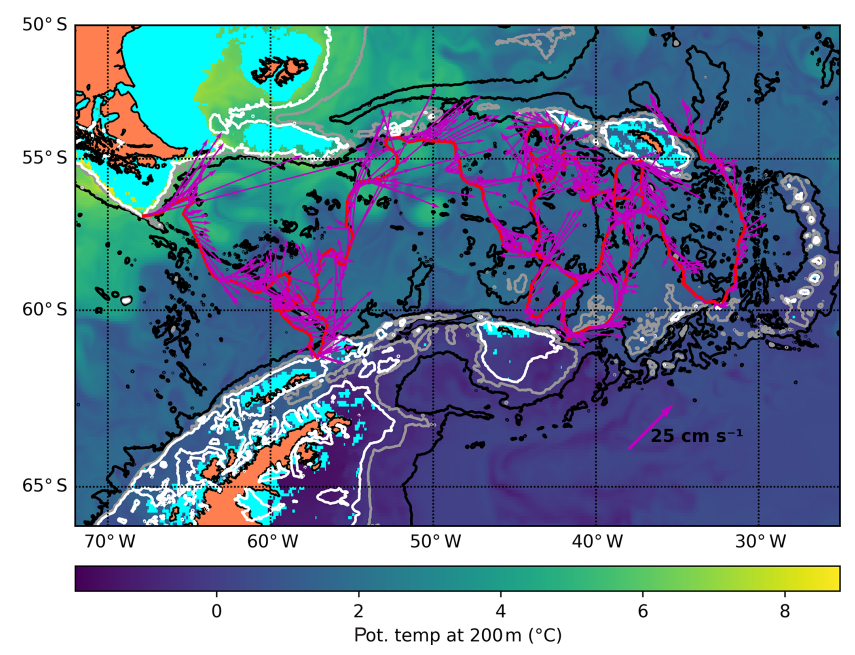

Figure 7. Slow glider trajectory in the Drake Passage, launched off the tip of South America (NW corner). Bathymetric contours are at 500, 1500 and $3000 \mathrm{~m}$. Mission ends at South Georgia Island.

\subsection{Discussion and summary}

In the Nordic Seas, the slow roaming glider or winged float would significantly complement the Argo float array in the area. The slow glider is able to sample fronts, eddies and boundary currents as well as basin interiors, whereas Argo floats tend to be constrained within the $2000 \mathrm{~m}$ isobath of the basin where they were launched (Voet et al., 2010).

The mission exemplified in the Nordic Seas targets the observation of the circulation and water mass properties at key locations in the Nordic Seas. This region is a key component of the Atlantic Meridional Overturning Circulation (AMOC), in which warm waters flow northward near the surface and cold waters return equatorward at depth. The variability of the Atlantic water characteristics is of importance to the climate in western Europe, to weather and sea ice conditions, and to primary production and fish habitats. The Nordic Seas are an important area for water mass transformation (Mauritzen, 1996; Isachsen et al., 2007). The newly produced or transformed dense waters return southward between Iceland and Greenland through Denmark Strait and east of Iceland across the Greenland-Scotland Ridge, contributing to the lower limb of the AMOC. Transects worked by a slow glider will provide crucial observations in the Norwegian Atlantic Current at Svinøy (Høydalsvik et al., 2013), in the deep convection regions in the Greenland and Iceland seas (Brakstad et al., 2019; Våge et al., 2018), and in the Lofoten Basin, which is a hotspot for Atlantic water transformation (Bosse et al., 2018). The transect in Fram Strait will capture the properties and variability in the return Atlantic water along the Polar Front in the northern Nordic Seas (de Steur et al., 2014). Particularly the interior Greenland and Iceland seas and the east Greenland shelf are under-sampled, and the observations will be useful in understanding the role of wintertime open-ocean convection in the western basins of the Nordic Seas and the effect of an ice edge in retreat toward Greenland (Moore et al., 2015; Våge et al., 2018).

Similarly, slow glider observations from the Gulf Stream and the Drake Passage mission examples will advance characterization of mean pathways, mesoscale variability and energetics in climatologically important regions. Furthermore, the Eulerian roaming will allow sampling of snapshots of mesoscale eddies. In the Lofoten Basin, a similar navigation option was used to spiral in and out of the Lofoten Basin Eddy by instructing the glider to fly at a set angle from the measured depth-averaged current (Yu et al., 2017). Profiles collected from such missions will be useful in characterizing the coherent eddy structures, filaments along fronts and around mesoscale eddies (see Testor et al., 2019, and the references therein). An additional strength of glider observations is the ability to infer absolute geostrophic currents (e.g. Høydalsvik et al., 2013). The transects resulting from Eulerian roaming are different than and less regular compared to the sections occupied by ship-based surveys, typically normal to the isobath orientation. Strong current speed exceeding the speed of gliders will result in oblique sampling. However, the local streamwise coordinate system (Todd et al., 2016), applied to for instance the Gulf Stream and the Loop Current, is demonstrated to be a powerful approach to calculate volume transport rates and potential vorticity structures and to provide insight into processes governing flow instabilities.

The key assumption in using the local streamwise coordinate system for geostrophic current calculations along the glider trajectory is that flow is parallel to the depth-averaged current (DAC). When the depth-average current direction is not perpendicular to the transect segment of the glider path, a decomposition into cross-track and along-track components must be made. In these conditions, using the currents from the local streamwise coordinate system will be an error; however, the transport will remain relatively unaffected. In a recent study, Bosse and Fer (2019) reported geostrophic velocities associated with the Norwegian Atlantic Front Current along the Mohn Ridge, using Seaglider data, following Todd et al. (2016) and assuming DAC is aligned with the baroclinic surface jet. They also calculated the geostrophic velocities and transports using the traditional method, i.e. across a glider track line, and found that the peak velocities of the frontal jet were $10 \%-20 \%$ smaller but the volume transports were identical to within error estimates. The Eulerian roaming can thus be used to obtain representative volume transport estimates of relatively well-defined currents. We also note that the present $1000 \mathrm{~m}$ depth capability of gliders limits our ability to compose the geostrophic currents into barotropic and baroclinic components in water depths substantially deeper than $1000 \mathrm{~m}$. A $2000 \mathrm{~m}$ range will allow us to more reliably approximate barotropic currents as the depth-averaged profile, up to depths of around $2000 \mathrm{~m}$. 
Regarding the navigation in general we note that it was easier and required less skill and intelligence in strong currents, when only a choice between left or right could be made (rule A); this often coincided with bathymetry (rule B). In weak currents, the navigational options increased, and we resorted to skilful and intelligent use of rules (C) and (D). The intelligence, however, does not seem to be very advanced as it essentially is an image processing task on the SSH image (albeit a vector image) for local steering decisions. Global steering decisions such as the general area to visit will require some oceanographic intelligence and are probably not suitable for automation.

The control and steering of a network or fleet of slow gliders should aim to optimize for some scientific objective, possibly in conjunction with other sensing platforms. Alvarez et al. (2007) have looked at synergies between floats and gliders to improve the reconstruction of the temperature field. Synergies also exists between a glider fleet and altimetry to map geostrophic currents (Alvarez et al., 2013). We suggest that future work should see the slow glider concept as part of a heterogenous suite of ocean sensing technologies. The topology of the network needs some consideration and one interesting option is to cluster the gliders in and near an oceanographic feature to explore it in greater detail. Some in situ experiments with glider fleets have been conducted (e.g. Leonard et al., 2010; Lermusiaux et al., 2017a). The problem of planning optimal paths for gliders is reviewed by Lermusiaux et al. (2017b).

While we have shown tracks of individual gliders, it should be clear that the impact of a slow roaming glider concept will increase when employed in large numbers. Also, the simulations here where a few gliders are hand-piloted does not show the full potential of the approach. Future simulations can include a large number of gliders to train artificial intelligence to perform the piloting.

\subsection{Outlook - altimetry, models and Argo}

The upcoming Surface Water and Ocean Topography (SWOT) altimetry mission (Fu and Ubelmann, 2014) will yield an unprecedented view of the ocean surface. Within the swath of the altimeter, approximately $120 \mathrm{~km}$ wide, we will see snapshots of oceanic mesoscale and sub-mesoscale structure and variability, albeit at a slower repeat cycle of $21 \mathrm{~d}$. However, advances in processing (Ubelmann et al., 2015) will likely fill the temporal gaps in a dynamically meaningful way, leading to maps of SSH with high temporal resolution, and enable operational model capabilities and applications hereto unimagined (Bonaduce et al., 2018).

There was always a strong coupling among altimetry, models and observations of ocean interior (Le Traon, 2013). The Argo programme's name was chosen because of its affinity with the then upcoming altimetric mission of the Jason satellites. Argo was the ship of Jason and the argonauts in their quest for knowledge. As altimetry advances, it is nec- essary to ask whether Argo and our quest for knowledge should advance in parallel. While SWOT altimetry will yield a (sub-)mesoscale view of the ocean, Argo remains primarily a basin- and seasonal-scale technology. We propose that the slow glider concept, essentially the gliding float that the Argo design specification calls for, could add a mesoscale component to Argo. This natural development enhances the Argo as a component of the global ocean observation system and supplements the regular glider operations, which are at present regional and process-oriented (Testor et al., 2009, 2019; Liblik et al., 2016).

Since we propose to steer the glider using maps of SSH and model output, the proposed slow glider would also provide an even tighter integration of altimetry, models and observations of ocean interior.

Other developments in the Argo programme further suggest a progression in this direction. Floats are increasingly being equipped with more advanced sensor suites in the biogeochemical programme (Riser et al., 2016; Roemmich et al., 2019). A new ArgoMix component with turbulence sensors (thermistors and airfoil shear probes), is also under consideration to map the spatial and temporal patterns of ocean mixing. The capabilities of the sensors call for a more advanced vehicle navigating the mesoscale ocean as well.

In the example missions presented here the glider is launched and recovered near the coast. Logistical challenges aside, this opens up new participatory dimensions with coastal communities. It might also be judged as a more environment friendly alternative to the Argo floats, which are submitted to the ocean upon mission completion.

While the tracks of the slow glider (or winged float) presented in this section clearly demonstrate oceanographic potential it remains to prove scientific value added to the existing network of Argo floats, regular gliders and altimetry. The scientific value could be explored and possibly quantified by an observing system simulation experiment which would include all observing elements of the Global Ocean Observing System, including our slow virtual glider. Such future work might build on the concepts and methods presented here. In Sect. 2.7 we roughly estimate that slow glider missions will cost 3 times more than a float mission, which requires that the scientific value be correspondingly enhanced if Stommel's vision is to be implemented in the form of slow gliders as we propose.

\section{Conclusions}

We show that oceanographically useful and sensible trajectories are possible with a slow roaming glider. Looking back at the quote from the Argo design specification in the Introduction, one might say that the expectations for a gliding float were too high. The notion of "a fixed location or along a programmed track" is not feasible due to energy constraints limiting velocity, nor is the notion indispensable or necessary. 
Even though we here mostly explore the concept of Eulerian roaming navigation, the slower and smaller glider will be able to maintain station (virtual mooring) or follow welldefined section lines at sites where currents are weak.

The velocity of $25 \mathrm{~cm} \mathrm{~s}^{-1}$ is unrealistic for endurance missions of years given the current status of battery (and/or energy harvesting) technology. The speed mentioned by Stommel (1989) in his vision was merely an example and should not be a constraint. We have shown that $13 \mathrm{~cm} \mathrm{~s}^{-1}$ can be sufficient to navigate the ocean giving due consideration to energy or power constraints.

Future work should firstly attempt to verify the concepts and findings presented here using existing gliders in the real ocean. The gliders should be operated at a lower speed than usual (refer to Fig. 3) and navigated as outlined in Sect. 3.1 and 3.3. Future work should also include observing system simulation experiments (e.g. L'Hévéder et al., 2013; Chapman and Sallée, 2017), whereby data assimilation from fleets of slow gliders demonstrates benefit and increased model skill in operational models. The piloting should also be automated, and work might be directed at developing artificial intelligence doing day-to-day piloting.

This paper demonstrates that slow gliders or Argo floats with wings are desirable and potentially feasible - the slow glide is on.

Data availability. The data used in this paper are made freely available by CMEMS (CMEMS, 2018) and in the World Ocean Atlas 2018 (https://www.nodc.noaa.gov/OC5/woa18/, last access: 27 February 2020).

Author contributions. EMB and IF wrote the paper with revisions and suggestions from KV and PMH. EMB performed the simulation experiments.

Competing interests. Ilker Fer is a member of the editorial board of Ocean Science, but other than that the authors declare that they have no conflict of interest.

Acknowledgements. The glider team at the Geophysical Institute spurred many interesting discussions about gliders and glider technology. The glider activities here were initially financed by the Research Council of Norway under grant no. 197316. We thank Lucas Merckelbach and Daniel Hayes, for their constructive review and criticism of our paper. Interested readers should consult their detailed remarks and consider them supplemental in the spirit of Ocean Science Discussion.

Financial support. Ketil Våge was supported by the Trond Mohn Foundation (grant no. BFS2016REK01).
Review statement. This paper was edited by Oliver Zielinski and reviewed by Lucas Merckelbach and Daniel Hayes.

\section{References}

Alvarez, A., Garau, B., and Caiti, A.: Combining networks of drifting profiling floats and gliders for adaptive sampling of the Ocean, Proceedings 2007 IEEE International Conference on Robotics and Automation, Roma, Italy, 10-14 April 2007, IEEE, https://doi.org/10.1109/ROBOT.2007.363780, 2007.

Alvarez, A., Chiggiato, J., and Schroeder, K.: Mapping sub-surface geostrophic currents from altimetry and a fleet of gliders, Deep-Sea Res. Pt. I, 74, 115-129, https://doi.org/10.1016/j.dsr.2012.10.014, 2013.

Anderson, J. D.: Fundamentals of Aerodynamics, 5th edn., McGraw-Hill, New York, ISBN 978-007-128908-5, 2011.

Argo: How do Argo floats work, Argo web pages, available at: http: //www.argo.ucsd.edu/How_Argo_floats.html, last access: 18 October 2019a.

Argo: FAQ - How much does the project cost and who pays?, Argo web pages, available at: http://www.argo.ucsd.edu/FAQ. html\#cost, last access: 21 October 2019b.

Bonaduce, A., Benkiran, M., Remy, E., Le Traon, P. Y., and Garric, G.: Contribution of future wide-swath altimetry missions to ocean analysis and forecasting, Ocean Sci., 14, 1405-1421, https://doi.org/10.5194/os-14-1405-2018, 2018.

Bosse, A. and Fer, I.: Mean structure and seasonality of the Norwegian Atlantic Front Current along the Mohn Ridge from repeated glider transects, Geophys. Res. Lett., 46, 13170-13179, https://doi.org/10.1029/2019GL084723, 2019.

Bosse, A., Fer, I., Søiland, H., and Rossby, T.: Atlantic water transformation along its poleward pathway across the Nordic Seas, J. Geophys. Res.-Oceans, 123, 6428-6448, https://doi.org/10.1029/2018JC014147, 2018.

Brakstad, A., Våge, K., Håvik, L., and Moore, G. W. K.: Water mass transformation in the Greenland Sea during the period 19862016, J. Phys. Oceanogr., 49, 121-140, 2019.

Chapman, C. and Sallée, J. B.: Can we reconstruct mean and eddy fluxes from Argo floats?, Ocean Model., 120, 83-100, 2017.

CMEMS: Product User Manual For the Global Ocean Physical Reanalysis product, available at: http://cmems-resources. cls.fr/documents/PUM/CMEMS-GLO-PUM-001-030.pdf (last access: 27 February 2020), Issue 1.1, also available at: http://marine.copernicus.eu/services-portfolio/ access-to-products/?option=com_csw\&view=details\&product_ id=GLOBAL_REANALYSIS_PHY_001_030 (last access: 30 March 2019), 2018.

Davis, R. E., Webb, D. C., Regier, L. A., and Dufour, J.: The Autonomous Lagrangian Circulation Explorer (ALACE), J. Atmos. Ocean. Tech., 9, 264-285, 1992.

Davis, R. E., Sherman, J. T., and Dufour, J.: Profiling ALACEs and Other Advances in Autonomous Subsurface Floats, J. Atmos. Ocean. Tech., 18, 982-993, 2001.

Davis, R. E., Eriksen, C. C., and Jones, C. P.: Autonomous Buoyancy-driven Underwater Gliders, in: The Technology and Applications of Autonomous Underwater Vehicles, edited by: Griffiths, G., Taylor and Francis, London, 37-58, 2002. 
Davis, R. E., Leonard, N. E., and Fratantoni, D. M.: Routing strategies for underwater gliders, Deep-Sea Res. Pt. II, 56, 173-187, 2009.

de Steur, L., Hansen, E., Mauritzen, C., Beszczynska-Moeller, A., and Fahrbach, E.: Impact of recirculation on the East Greenland Current: results from moored current meter measurements between 1997 and 2009, Deep-Sea Res. Pt. I, 92, 26-40, 2014.

Eriksen, C. C., Osse, T. J., Light, R. D., Wen, T., Lehman, T. W., Sabin, P. L., Ballard, J. W., and Chiodi, A. M.: Seaglider: A Long-Range Autonomous Underwater Vehicle for Oceanographic Research, IEEE J. Oceanic Eng., 26, 424-436, 2001.

Frajka-Williams, E., Eriksen, C. C., Rhines, P. B., and Harcourt, R. R.: Determining Vertical Water Velocities from Seaglider, J. Atmos. Ocean. Tech., 28, 1641-1656, 2011.

Fu, L.-L. and Ubelmann, C.: On the Transition from Profile Altimeter to Swath Altimeter for Observing Global Ocean Surface Topography, J. Atmos. Ocean. Tech., 31, 560-568, https://doi.org/10.1175/JTECH-D-13-00109.1, 2014.

Garau, B., Ruiz, S., Zhang, W. G., Pascual, A., Heslop, E., Kerfoot, J., and Tintoré, J.: Thermal Lag Correction on Slocum CTD Glider Data, J. Atmos. Ocean. Tech., 28, 1065-1071, 2011.

Gould, W. J.: From Swallow floats to Argo-the development of neutrally buoyant floats, Deep-Sea Res. Pt. II, 52, 529-543, 2005.

Graver, J. G.: Underwater Gliders: Dynamics, Control and Design, PhD thesis, Princeton University, USA, 2005.

Hoerner, S. F.: Fluid-dynamic Drag, Hoerner Fluid Dynamics, Bakersfield, CA, USA, LCCCN 64-19666, 1965.

Høydalsvik, F., Mauritzen, C., Orvik, K. A., LaCasce, J. H., Lee, C. M., and Gobat, J.: Transport estimates of the Western Branch of the Norwegian Atlantic Current from glider surveys, Deep-Sea Res. Pt. I, 79, 86-95, 2013.

IOC, SCOR, and IAPSO: The international thermodynamic equation of seawater - 2010: calculations and use of thermodynamic properties, Intergovernmental Oceanographic Commission, UNESCO, Manuals and Guides No. 56, 196 pp., 2010.

Isachsen, P. E., Mauritzen, C., and Svendsen, H.: Dense water formation in the Nordic Seas diagnosed from sea surface buoyancy fluxes, Deep-Sea Res. Pt. I, 54, 22-41, 2007.

Jagadeesh, P., Murali, K., and Idichandy, V. G.: Experimental investigation of hydrodynamic force coefficients over AUV hull form, Ocean Eng., 36, 113-118, 2009.

Jenkins, S. A., Humphreys, D. E., Sherman, J., Osse, J., Jones, C., Leonard, N., Graver, J., Bachmayer, R., Clem, T., Carrol, P., Davis, P., Berry, J., Worley, P., and Wasyl, J.: Underwater Glider System Study, Scripps Institution of Oceanography, UC San Diego, Technical Report No. 53, 242 pp., 2003.

Khoury, G. A. and Gillett, J. D. (Eds.): Airship Technology, Cambridge University Press, Cambridge, UK, ISBN 978$0521430746,1999$.

Kobayashi, T., Asakawa, K., Watanabe, K., Ino, T., Amaike, K., Iwamiya, H., Tachikawa, M., Shikama, N., and Mizuno, K.: New buoyancy engine for autonomous vehicles observing deeper oceans, in: Proc. 20th International Offshore and Polar Engineering Conference,Beijing, China, 20-25 June 2010, International Society of Offshore and Polar Engineers, 2, 401-405, 2010.

Le Traon, P. Y.: From satellite altimetry to Argo and operational oceanography: three revolutions in oceanography, Ocean Sci., 9, 901-915, https://doi.org/10.5194/os-9-901-2013, 2013.
Lee, C. M. and Rudnick, D. L.: Underwater Gliders, in Observing the Oceans in Real Time, Springer Oceanography, Cham, Switzerland, ISBN 978-3-319-66492-7, 2018.

Lekien, F., Mortier, L., and Testor, P.: Glider Coordinated Control and Lagrangian Coherent Structures, IFAC Proceedings Volumes, 41, 125-130, 2008.

Lellouche, J.-M., Greiner, E., Le Galloudec, O., Garric, G., Regnier, C., Drevillon, M., Benkiran, M., Testut, C.-E., BourdalleBadie, R., Gasparin, F., Hernandez, O., Levier, B., Drillet, Y., Remy, E., and Le Traon, P.-Y.: Recent updates to the Copernicus Marine Service global ocean monitoring and forecasting realtime $1 / 12^{\circ}$ high-resolution system, Ocean Sci., 14, 1093-1126, https://doi.org/10.5194/os-14-1093-2018, 2018.

Leonard, N. E., Paley, D. A., Davis, R. E., Fratantoni, D. M., Lekien, F., and Zhang, F.: Coordinated control of an underwater glider fleet in an adaptive ocean sampling field experiment in Monterey Bay, J. Field Robot., 27, 718-740, https://doi.org/10.1002/rob.20366, 2010.

Lermusiaux, P. F. J., Haley Jr., P. J., Jana, S., Gupta, A., Kulkarni, C. S., Mirabito, C., Ali, W. H., Subramani, D. N., Dutt, A., Lin, J., Shcherbina, A. Y., Lee, C. M., and Gangopadhyay, A.: Optimal planning and sampling predictions for autonomous and Lagrangian platforms and sensors in the northern Arabian Sea, Oceanography 30, 172-185, https://doi.org/10.5670/oceanog.2017.242, 2017a.

Lermusiaux, P. F. J., Subramani, D. N., Lin, J., Kulkarni, C. S., Gupta, A., Dutt, A., Lolla, T., Haley Jr., P. J., Ali, W. H., Mirabito, C., and Jana, S.: A future for intelligent autonomous ocean observing systems, J. Mar. Res., 75, 765-813, https://doi.org/10.1357/002224017823524035, 2017b.

L'Hévéder, B., Mortier, L., Testor, P., and Lekien, F.: A Glider Network Design Study for a Synoptic View of the Oceanic Mesoscale Variability, J. Atmos. Ocean. Tech., 30, 1472-1493, 2013.

Liblik, T., Karstensen, J., Testor, P., Alenius, P., Hayes, D., Ruiz, S., Heywood, K. J., Pouliquen, S., Mortier, L., and Mauri, E.: Potential for an underwater glider component as part of the Global Ocean Observing System, Methods in Oceanography, 17, 50-82, 2016.

Lidtke, A. K., Turnock, S. R., and Downes, J.: Hydrodynamic Design of Underwater Gliders Using $\mathrm{k}^{-\mathrm{k}_{L}}-\omega$ Reynolds Averaged Navier-Stokes Transition Model, IEEE J. Oceanic Eng., 43, 2, 356-368, 2018.

Locarnini, R. A., Mishonov, A. V., Baranova, O. K., Boyer, T. P., Zweng, M. M., Garcia, H. E., Reagan, J. R., Seidov, D., Weathers, K., Paver, C. R., and Smolyar, I.: World Ocean Atlas 2018, Volume 1: Temperature, edited by: Mishonov, A., NOAA Atlas NESDIS 81, 52 pp., 2018.

Lueck, R. G. and Picklo, J. J.: Thermal inertia of conductivity cells: Observations with a Sea-Bird cell, J. Atmos. Ocean. Tech., 7, 756-768, 1990.

Mauritzen, C.: Production of dense overflow waters feeding the North Atlantic across the Greenland-Scotland Ridge. Part 1: evidence for a revised circulation scheme, Deep-Sea Res. Pt. I, 43, 769-806, 1996.

McMasters, J. H.: An Analytic Survey of Low Speed Flying Devices - Natural and Man-Made, Technical Soaring, 3, 17-42, 1974. 
Merckelbach, L., Smeed, D., and Griffiths, G.: Vertical Water Velocities from Underwater Gliders, J. Atmos. Ocean. Tech., 27, 547-563, 2010.

Merckelbach, L., Berger, A., Krahmann, G., Dengler, M., and Carpenter, J.: A dynamic flight model for Slocum gliders and implications for turbulence microstructure measurements, J. Atmos. Ocean. Tech., 36, 281-296, https://doi.org/10.1175/JTECH-D18-0168.1, 2019.

Moore, G. W. K., Våge, K., Pickart, R. S., and Renfrew, I. A.: Decreasing intensity of open-ocean convection in the Greenland and Iceland seas, Nat. Clim. Change, 5, 877-882, 2015.

Osse, T. J. and Eriksen, C. C.: The Deepglider: A Full Ocean Depth Glider for Oceanographic Research, OCEANS 2007, Vancouver, BC, Canada, 29 September-4 October 2007, IEEE, https://doi.org/10.1109/OCEANS.2007.4449125, 2007.

Owens, B., Roemmich, D., and Dufour, J.: Status of SOLO-II Floats Development, presentation given to the Argo Steering Team meeting No. 13, Paris, France, available at: http://www.argo. ucsd.edu/AST13_SOLO-II_Status.pdf (last access: 27 February 2020), 2012.

Renfrew, I. A., Pickart, R. S., Våge, K., Moore, G. W., Bracegirdle, T. J., Elvidge, A. D., Jeansson, E., Lachlan-Cope, T., McRaven, L. T., Papritz, L., Reuder, J., Sodemann, H., Terpstra, A., Waterman, S., Valdimarsson, H., Weiss, A., Almansi, M., Bahr, F., Brakstad, A., Barrell, C., Brooke, J. K., Brooks, B. J., Brooks, I. M., Brooks, M. E., Bruvik, E. M., Duscha, C., Fer, I., Golid, H. M., Hallerstig, M., Hessevik, I., Huang, J., Houghton, L., Jónsson, S., Jonassen, M., Jackson, K., Kvalsund, K., Kolstad, E. W., Konstali, K., Kristiansen, J., Ladkin, R., Lin, P., Macrander, A., Mitchell, A., Olafsson, H., Pacini, A., Payne, C., Palmason, B., Pérez-Hernández, M. D., Peterson, A. K., Petersen, G. N., Pisareva, M. N., Pope, J. O., Seidl, A., Semper, S., Sergeev, D., Skjelsvik, S., Søiland, H., Smith, D., Spall, M. A., Spengler, T., Touzeau, A., Tupper, G., Weng, Y., Williams, K. D., Yang, X., and Zhou, S.: The Iceland Greenland Seas Project, B. Am. Meteorol. Soc., 100, 1795-1817, https://doi.org/10.1175/BAMS-D18-0217.1, 2019.

Riser, S. C., Freeland, H. J., Roemmich, D., Wijffels, S., Troisi, A., Belbéoch, A., Gilbert, D., Xu, J., Pouliquen, S., Thresher, A., Le Traon, P. Y., Maze, G., Klein, B., Ravichandran, M., Grant, F., Poulain, P. M., Suga, T., Lim, B., Sterl, A., Sutton, P., Mork, K. A., Vélez-Belchí, P. J., Ansorge, I., King, B., Turton, J., Baringer, M., and Jayne, S. R.: Fifteen years of ocean observations with the global Argo array, Nat. Clim. Change, 6, 145-153, 2016.

Roemmich, D., Boebel, O., Freeland, H., King, B., Le Traon, P. Y., Molinari, R., Brechner Owens, W., Riser, S., Send, U., Takeuchi, K., and Wijffels, S.: On The Design and Implementation of Argo - A Global Array of Profiling Floats, available at: http://www. argo.ucsd.edu/argo-design.pdf (last access: 27 February 2020), 1999.

Roemmich, D., Johnson, G. C., Riser, S., Davis, R., Gilson, J., Brechner Owens, W., Garzoli, S. L., Schmid, C., and Ignaszewski, M.: The Argo Program: Observing the Global Ocean with Profiling Floats, Oceanography, 22, 34-43, 2009.

Roemmich, D., Alford, M., Claustre, H., Johnson, K., King, B., Moum, J., Oke, P., Brechner, Owens, W., Pouliquen, S., Purkey, S., Scanderbeg, M., Suga, T., Wijffels, S., Zilberman, N., Bakker, D., Baringer, M., Belbeoch, M., Bittig, H. C., Boss, E., Calil, P., Carse, F., Carval, T., Chai, F., Conchubhair, D. Ó., d'Ortenzio,
F., Dall'Olmo, G., Desbruyeres, D., Fennel, K., Fer, I., Ferrari, R., Forget, G., Freeland, H., Fujiki, T., Gehlen, M., Greenan, B., Hallberg, R., Hibiya, T., Hosoda, S., Jayne, S., Jochum, M., Johnson, G. C.., Kang, K., Kolodziejczyk, N., Körtzinger, A., Le Traon, P.-Y., Lenn, Y.-D., Maze, G., Mork, K. A., Morris, T., Nagai, T., Nash, J., Garabato, A. N., Olsen, A., Pattabhi, R. R., Prakash, S., Riser, S., Schmechtig, C., Schmid, C., Shroyer, E., Sterl, A., Sutton, P., Talley, L., Tanhua, T., Thierry, V., Thomalla, S., Toole, J., Troisi, A., Trull, T. W., Turton, J., Velez-Belchi, P. J., Walczowski, W., Wang, H., Wanninkhof, R., Waterhouse, A. F., Waterman, S., Watson, A., Wilson, C., Wong, A. P. S., Xu, J., and Yasuda, I.: On the future of Argo: An enhanced global array of physical and biogeochemical sensing floats, Frontiers in Marine Science, 6, 439, https://doi.org/10.3389/fmars.2019.00439, 2019.

Rudnick, D. L.: Ocean Research Enabled by Underwater Gliders, Annu. Rev. Mar. Sci., 8, 519-541, https://doi.org/10.1146/annurev-marine-122414-033913, 2016.

Rudnick, D. L., Sherman, J. T., and Wu, A. P.: Depth-Average Velocity from Spray Underwater Gliders, J. Atmos. Ocean. Tech., 35, 1665-1673, https://doi.org/10.1175/JTECH-D-170200.1, 2018.

Schmitz, F. W.: Aerodynamik des Flugmodels - Tragfluegelmessungen I + II bei kleinen Geschwindigkeiten, Luftfahrtverlag Walter Zuerl, Steinebach-Woerthsee, Germany, 6th printing/edn., 1975.

Sherman, J., Davis, R. E., Owens, W. B., and Valdes, J.: The Autonomous Underwater Glider “Spray”, IEEE J. Oceanic Eng., 26, 437-446, 2001.

Stommel, H.: The Slocum Mission, Oceanography, 2, 22-25, 1989.

Sunada, S., Yasuda, T., Yasuda, K., and Kawachi, K.: Comparison of Wing Characteristics at an Ultralow Reynolds Number, J. Aircraft, 39, 331-338, 2002.

Testor, P., Meyers, G., Pattiaratchi, C., Bachmayer, R., Hayes, D., Pouliquen, S., Petit de la Villeon, L., Carval, T., Ganachaud, A., Gourdeau, L., Mortier, L., Claustre, H., Taillandier, V., Lherminier, P., Terre, T., Visbeck, M., Karstensen, J., Krahmann, G., Alvarez, A., Rixen, M., Poulain, P.-M., Osterhus, S., Tintore, J., Ruiz, S., Garau, B., Smeed, D., Griffiths, G., Merckelbach, L., Sherwin, T., Schmid, C., Barth, J. A., Schofield, O., Glenn, S., Kohut, J., Perry, M. J., Eriksen, C., Send, U., Davis, R., Rudnick, D., Sherman, J., Jones, C., Webb, D., Lee, C., and Owens, B.: Gliders as a component of future observing systems, in: Proceedings of the OceanObs' 09 conference: ocean information for society: sustaining the benefits, realizing the potential, Venice, Italy, 21-25 September 2009, edited by: Hall, J., Harrison, D. E., and Stammer, D., ESA, WWP-306, 22 pp., 2009.

Testor, P., de Young, B., Rudnick, D. L., Glenn, S., Hayes, D., Lee, C. M., Pattiaratchi, C., Hill, K., Heslop, E., Turpin, V., Alenius, P., Barrera, C., Barth, J. A., Beaird, N., Bécu, G., Bosse, A., Bourrin, F., Brearley, J. A., Chao, Y., Chen, S., Chiggiato, J., Coppola, L., Crout, R., Cummings, J., Curry, B., Curry, R., Davis, R., Desai, K., DiMarco, S., Edwards C, Fielding, S., Fer, I., Frajka-Williams, E., Gildor, H., Goni, G., Gutierrez, D., Haugan, P., Hebert, D., Heiderich, J., Henson, , S., Heywood, K., Hogan, P., Houpert, L., Huh, S., Inall, M. E., Ishii, M., Ito, S.-i., Itoh, S., Jan, S., Kaiser, J., Karstensen, J., Kirkpatrick, B., Klymak, J., Kohut, J., Krahmann, G., Krug, M., McClatchie, S., Marin, F., Mauri, E., Mehra, A. P., Meredith, M. 
P., Meunier, T., Miles, T., Morell, J. M., Mortier, L., Nicholson, S., O'Callaghan, J., O’Conchubhair, D., Oke, P., Pallàs-Sanz, E., Palmer, M., Park, J., Perivoliotis, L., Poulain, P. M., Perry, R., Queste, B., Rainville, L., Rehm, E., Roughan, M., Rome, N., Ross, T., Ruiz, S., Saba, G., Schaeffer, A., Schönau, M., Schroeder, K., Shimizu, Y., Sloyan, B. M., Smeed, D., Snowden, D., Song, Y., Swart, S., Tenreiro, M., Thompson, A., Tintore, J., Todd, R. E., Toro, C., Venables, H., Wagawa, T., Waterman, S., Watlington, R. A., and Wilson, D.: OceanGliders: A Component of the Integrated GOOS, Frontiers in Marine Science, 6, 422, https://doi.org/10.3389/fmars.2019.00422, 2019.

Thomas, F.: Fundamentals of Sailplane Design - Grundlagen fuer den Entwurf von Segelflugzeugen, College Park Press, Maryland, USA, ISBN 0-9669553-0-7, 1999.

Todd, R. E., Brechner Owens, W., and Rudnick, D. L.: Potential Vorticity Structure in the North Atlantic Western Boundary Current from Underwater Glider Observations, J. Phys. Oceanogr., 46, 327-348, 2016.

Ubelmann, C., Klein, P., and Fu, L. L.: Dynamic Interpolation of Sea Surface Height and Potential Applications for Future High-Resolution Altimetry Mapping, J. Atmos. Ocean. Tech., $32,177-184,2015$.
Voet, G., Quadfasel, D., Mork, K. A., and Søiland, H.: The middepth circulation of the Nordic Seas derived from profiling float observations, Tellus A, 62, 516-529, 2010.

Våge, K., Papritz, L., Håvik, L., Spall, M. A., and Moore, G. W. K.: Ocean convection linked to the recent ice edge retreat along east Greenland, Nat. Commun., 9, 1287, https://doi.org/10.1038/s41467-018-03468-6, 2018.

Webb, D. C.: Variable buoyancy device, U.S. Patent 7,096,814 B1, issued 29 August 2006.

Webb, D. C., Simonetti, P. J., and Jones, C. P.: SLOCUM: An Underwater Glider Propelled by Environmental Energy, IEEE J. Oceanic Eng., 26, 447-452, 2001.

Yu, L. S., Bosse, A., Fer, I., Orvik, K. A., Bruvik, E. M., Hessevik, I., and Kvalsund, K.: The Lofoten Basin eddy: Three years of evolution as observed by Seagliders, J. Geophys. Res.-Oceans, 122, 6814-6834, https://doi.org/10.1002/2017JC012982, 2017.

Zweng, M. M., Reagan, J. R., Seidov, D., Boyer, T. P., Locarnini, R. A., Garcia, H. E., Mishonov, A. V., Baranova, O. K., Weathers, K., Paver, C. R., and Smolyar, I.: World Ocean Atlas 2018, Volume 2: Salinity, edited by: Mishonov, A., NOAA Atlas NESDIS 82, 50 pp., 2018. 